\title{
Environmental Education: Swimming With the Tide
}

\author{
A. F. Ibimilua ${ }^{1} \&$ S. A. Amuno $^{2}$ \\ ${ }^{1}$ Ekiti State University, Ado-Ekiti, Nigeria \\ ${ }^{2}$ Geoforensic Environmental Services, Toronto, Canada \\ Correspondence: A. F. Ibimilua, Faculty of the Social Sciences, Department of Geography and Planning Science, \\ Ekiti State University, Ado-Ekiti, Nigeria. E-mail: wibimilua@yahoo.com
}

Received: May 12, 2014 Accepted: May 16, 2014 Online Published: September 14, 2014

doi:10.5539/jsd.v7n5p32 URL: http://dx.doi.org/10.5539/jsd.v7n5p32

\begin{abstract}
This paper examines the necessity to embrace and adopt environmental education. Essentially, environmental education has to do with the creation of awareness and spread of knowledge and understanding about the environment and environmental challenges. Fundamentally, it deals with decision making about environmental actions. Hence, it engages in actions to improve and sustain the environment. Environmental education is about good governance. It is highly indispensable. It is required in solving environmental problems with unimaginable consequences. On this note, the salient issues addressed in this paper are human-environment interaction, environmental awareness, environmental literacy, and sustainability. The reviewed literature revealed that the level of environmental education in developed countries of the world is far higher than that of the developing countries. To this end, this study recommends that the developing countries should move with the tide in terms of environmental education. They should attach more value to the environment. Moreover, they should promote responsible behavior towards the environment. Above all, individuals, institutions the government, non-governmental organizations, as well as community-based organizations should be involved in environmental education.
\end{abstract}

Keywords: awareness, education, environment, knowledge, management, sustainability

\section{Introduction}

Environmental sustainability is one of the major issues that are in vogue in contemporary civilization. It is a crucial prerequisite to other concomitants of environmental management and sustainable development (see Anil \& Arnub, 2014). Others include environmental impact assessment, environmental sustainability environmental movements, environmental cost benefit analysis environmental quality assessment, and environmental management and planning. Environmental education includes thinking scientifically about the environment. It involves the understanding of the inter-relationships that exist between human and his environment. It is occasioned by the creation of awareness and concern about global environmental issues like hazards and risks, decline in native species, climate change, waste disposal, oil spillage, pollution, global warming, destruction of forest, hedge grow loss, and environmental degradation.

The concern for the environment is based on the premise that there are so many ways through which human is affecting his environment. Also, some environmental problems that were confined to some specific localities are now national or global problems. Apart from this, the effects of the consequences of some environmental problems are irreversible on human and his environment. This concern geared up environmental education. Consequently, environmental education helps people to develop the cognitive skills of decision making and problem solving. Also, it tells us the course of action, solutions to environmental problems, as well as alternative actions. Thus, environmental education teaches us how to think about the environment, helps people to investigate issues, weigh various sides of issues and take the appropriate decision. Environmental education is needed in order to counteract the careless intervention in the environment through the use of available technology and excessive power, coupled with human greed for lavish consumption which can eventually lead to environmental degradation and resources depletion, which could ultimately serve as seeds for future local, national and international unrests and conflicts (Santra, 2011: 981).

Environmental education informs us about the changes that are taking place in the environment as well as their negative consequences. It therefore becomes a necessity in the recent time because some people are ignorant of, 
or insufficiently sensitized to issues relating to environmental problems, conservation, and degradation, as well as their impact on human health, welfare, and indeed, the survival of the human species. (see Andrejs, Dan \& Kelly, 2013; Ademiluyi \& Solanke, 2004; Adetuberu, 2003; Agbodi \& Ofuoku, 2007; Ibimilua \& Ibimilua, 2011).

It is the people's education which holds the key to environmental management and good quality of life (Anil \& Arnab, 2014). Environmental education enlightens us about the relationship between human and his environment Hence, the study of human-environment interaction and invariably, environmental education is required in the sustainable use of environmental resources. Environmental education borders on the fact that resources are scarce and some of them are not renewable. Resources are not limitless. Some are being used, others are latent and not yet being used to their full potential, but are ultimately limited in supply. Even those that are renewable are limited in supply at any one moment (Charles, 1979: 76).

Raven, Berg and Hassenzahl (2010) placed more emphasis on public education and involvement as an appendage of environmental education. According to them, public awareness and endorsement are an essential part of addressing environment problems. They noted further that when alternative courses of action exist, the public must be consulted. To this end, citizen's participation is required in environmental education. It is essential for the dissemination of training and other activities on the sustainable use of environmental resources. Also, formal and informal education is required in order to save the environment from further degradation. Moreover, accurate information about the functioning system of the environment as well as how to combat environmental problems are needed in order to achieve environmental sustainability.

There is the need to embrace environmental education (see Ibimilua, 2013; Ibimilua, 2014). The focus of environmental education should be on the mode of human-environment interactions. This is in the hope of highlighting in good time the consequences of whatever form of interaction human engaged with his environment. The effect of this type of development will be the emergence of a healthy environment that holds a lot of prosperity for both the present and the future generations (Jimoh, 2000:25). In this sense, environmental education is seen as an agent of change. The main objective of environmental education therefore is to induce positive change and to halt detrimental change. Thus, it is seen as a major tool in the attainment of sustainable development (see Umoren, 2005; Debbie, 2013; Andrejs, Dan \& Kelly, 2013).

\section{The Human Environment}

Numerous scholars have considered the human environment in different ways. For instance, Ibitoye (2004) referred to the environment as the home of humans. That is, the surroundings, circumstances and influences that acts on human wherever he lives. Also, Kanagasabai (2010:1) perceived the environment as all natural things around us, which sustain human life, such as earth's atmosphere or healthy air or drinkable water. He defined the environment as an outer physical and biological system in which human and other organisms live with many interacting components. Also, to Akinbode (2002:1), the environment refers to the totality of the places and the surroundings in which we live, work and interact with other people in our cultural, religious, political and socio-economic activities for self-fulfilment and the advancement our communities, societies or nations.

Moreover, Santra (2011: 1219) defined the environment as all external conditions and factors, living and nonliving (chemical and energy), that affect an organism or other specified system during its lifetime; the earth's life-support systems for us and for all other forms of life. In the same vein, Botkin and Keller (2012) perceived the environment as all the factors (living and non living) that actually affect an individual organism or population at any point in the life cycle. Similarly, Wright and Boorse (2011: 369) defined the environment as the combination of all things and factors external to the individual or population of organism in questions. From all the above definitions, we can deduce that the environment can be viewed from socio, economic, political, geographical, scientific, and management, perspectives. However, from whichever angle we are looking at it, the environment refers to the totality of that which surrounds human and which are also capable of influencing him.

The environment can be subdivided into three main components - air, water and land. These components provide the conditions for the development and growth of communities of organism's plants and animals (including humans) (Hyde \& Reeve, 2011:9). Living organisms (including humans) depend on the basic constituents of the environment like the atmospheric gases and water for their life performance. This process is known as human-environment interaction. However of all organisms, human is having the most significant influence on the environment. He has the technology and the ability to manipulate the environment in order to suit his purpose. He interacts with the environment in order to satisfy his needs including shelter, clothing and food.

In the process of harnessing environmental resources, human does a lot of damages to the environment (see 
Ibimilua, 2013; Ibimilua, 2014; Ibimilua \& Ibimilua, 2014). Many of these are done out of ignorance of the working mechanism of the environment. In support of this, Holden (2008:22) noted that many of the world's environmental problems lie in unsound human knowledge and management of the environment. He opined further that humans have the potential to recognize and respond to opportunities and to threats that are natural or caused by human and perhaps avoid or mitigate them. Nevertheless, other authors have argued that there are other reasons why environmental damages occur, beyond ignorance of the working mechanism of the environment. Such damages occur during the execution of development projects in the environment (see Debbie, 2013; Holdan, 2008; Ike, 2002; Jimoh, 2000; Umoran, 2005).

\section{Environmental Awareness}

Environmental awareness is based on the premise that environmental deterioration has become an ever-present and growing concern for people and government throughout the world (see Felman, Getis \& Getis, 2008). Knowledge about the environment-especially its holistic nature and the laws that govern the on-going process in the environment particularly in an ecosystem and the interdependence of different elements in the environment is a priority need for a better understanding, protection and improvement of the environment (Santra, 2011: 981). Hence, environmental awareness means the use of the individuals, groups, organizations, and the media in order to inform, mobilize and sensitize people about environmental issues. It consists of measures taken in order to predict disasters and where possible to prevent them (Siyanbade, 2006: 47).

Environmental awareness among the public and policy makers has been growing since the 1960s, when it became widely recognized that human activities were having harmful and large scale effects on the environment (Mahatma, 2009: 3). It is a global issue and it is of major concern in developed countries of the world. However, the level of environmental awareness as well as the campaign for environmental literacy is very low in developing countries of the world. Nevertheless, it should be a global agenda to be embraced by both the North and the South countries.

Awareness is about the enlightenment and sensitisation of the public about the negative effects of natural hazards and anthropogenic problems. It is ideal to have the rudimentary knowledge of the circulation system in the atmosphere, the continuous interchange of both geographical position and physical state in the hydrosphere, the rock cycle in the lithosphere, as well as the flow of energy in the biosphere.

Enhancing environmental awareness is essential to harmonize patterns of individual behaviour with the requirements of environmental conservation (Jain \& Rao, 2011:941). Environmental awareness helps us in the protection of environmental amenities. Also, it assists us in the conservation of resources. Above all, it is a major tool in the achievement of sustainable development. To this end, Cunningham and Cunningham (2006:3) noted that the awareness being gained by scientists is fundamental to our ability to manage the earth's resources in a sustainable manner and to improve the quality of our lives and those of our children.

Environmental awareness helps us to suppress the pressures on the environment (see Raven et al, 2010). Such problems include existence of growth of slum, waste management problem, pressure on natural habitats, pollution (of various types), health hazards, crime (of various dimensions), climate change, indiscriminate bush burning, habitat loss, extinction of rare species, disease outbreak and other ecological problems (see Ibimilua \& Ibimilua, 2011: 75 for greater details).

Furthermore, Ademiluyi and Solanke (2004: 158) noted that care free attitude of humans account for numerous problems in the environment in the course of human's socio-economic activities. The bad attitude results from inadequate awareness about the processes that are responsible for environmental problems. These include pollution, flooding, biodiversity loss, deforestation, and bush burning to mention a few. The Natural Environment Research Council (2006) observed that the prediction and understanding of the natural process that are responsible for a hazard will assist in no small measure in solving the problems that are relevant to human safety, planning and insurance.

In order to manage environmental problems we need to have the understanding of environmental processes in itself. We need to be familiar with the causes and consequences of environmental problems so as to be able to predict their occurrence and mitigate their consequences. This study, therefore, provides more general ideas about the necessity to be aware of the types, causes, consequences, preparedness and mitigation of environmental problems.

\section{Environmental Education}

Education refers to the development of the powers of the human mind (Kwame, 2008:249). It involves bringing up and passing instruction, knowledge or skill from one person to another. It means training or teaching 
somebody. It could also be referred to as an attempt to refine somebody in judgement. Environmental education, therefore, means the act of teaching or training people about the working system of the environment. It hinges upon the need to create and maintain congenial environment. It deals with public enlightenment to prevent environmental hazards, or to reduce the effects of environmental problems. It involves the implementation of actions to improve and sustain the environment.

Researches have confirmed that the root of environmental education can be traced back to the $18^{\text {th }}$ century and that the modern environmental movement has gained ground in many developed nations like Norway, Australia, Netherlands, United States of America, New Zeeland, Canada, Ireland, Germany and Sweden for several decades. On the other hand, more momentum is still needed in environmental education in many developing countries like Nepal, Cambodia, Sudan and Rwanda to mention a few (see Cecil, 2014; Ibimilua, 2014; Ibimilua \& Ibimilua, 2014 for greater details). In spite of its urgent need, the study of environment, i.e. environmental education in India remains largely neglected. Only 25 out of 250 universities including Jawaharlal Nehru University (JNU), Cochin University, Pondicherry University, etc., offer courses (M.Sc.) in Environmental Sciences (Anil \& Arnab, 2014: 13).

Works that have been done within environmental education towards sustainable development in Nigeria include; Agbogidi \& Ofuoku (2007). They examined the roles of women in environmental education in order to promote environmental protection in Nigeria. Findings from their study revealed that Nigeria is faced by serious environmental challenges like deforestation, pollution, land degradation, urbanization and climate change. They opined that population pressure and inadequate environmental awareness are the major courses of the environmental challenges. On this note, they recommended strong emphasis on environmental education not only through schools and colleges but also through training and industry as well as through community activities.

Several authors have argued that environmental education is required in solving environmental problems (See Fatubarin, 2009a; Fatubarin, 2009b; Ibimilua \& Ibimilua, 2011; Franca, 2002; Pepper, 1996; Park, 1997; Adetuberu, 2003; Oriodan, 1976; Peters, 1995; Caldwell, 1973; Ike, 2002; Jimoh, 2000; Stanley, 2010). Thus, environmental education becomes necessary because of the multi-dimensional characteristics of environmental problems. Most of the predicaments are caused by the human interference with the environment. Hence, environmental education provides detailed information about the environment. It guides against the destructive or inhuman practices of human against the environment. It gives us the awareness of the importance and beauty of the environment as well as the necessity to preserve it. However, it lays more emphasis on preventive measures of environmental problems than the curative measures.

Environmental education is multi-disciplinary in its perspective. It covers disciplines like nature study, conservation, environmental psychology, environmental management, and urban planning. Likewise, it is related to disciplines like engineering, law, medicine and history. Thus, training in environmental issues involves the acquisition of techniques and approaches borrowed from other related disciplines. Also, it cuts, across both formal and informal learning processes. Consequently, environmental education combines teaching resources, human resources, traditional practices, methods, and conceptual backgrounds of many related disciplines in order to tackle major environmental challenges.

Jimoh (2000: 26) opined that environmental education programmes are possible ways of resolving the discomforts on human and his properties. He noted further that the best form in which human can interact with his environment and minimize the incidence of environmental stress is to first understand the entire morphology of his environment. Hence, the application of environmental education requires the creation of awareness about issues bordering on climate change, pollution, biodiversity loss, acid deposition, land contamination, resource depletion, general air quality and ozone depletion.

Akinibode (2002) pointed out that environmental education is borne out of the fact that environmental resources are essential for attaining and sustaining development at a high level of human welfare. In the course of harnessing environmental resources, human is always doing some damages to the environment and its components. Similarly, Madu (2007) noted that human activities have modified the organic and inorganic features of the earth, and that people affect the environment through their use and abuse of natural resources and production of wastes. Thus, environmental education focuses its attention on sustainable human-environment interaction. It borders on how we can use the value of local knowledge, perception, and practices in ensuring environmental sustainability. As such, it focuses on the present situation and lays more emphasis on future environmental condition.

Environmental education must create an awareness of the economic, political and ecological interdependence of the modern world so as to enhance a spirit of responsibility and solidarity among nations and people 
(Kanagasabai, 2010:10). In this regard, it is meant to create the awareness and sensitivity about the environment and the challenges therein. It hinges upon the concern for the environment and the need to maintain high environmental quality. To achieve this, modern techniques of environmental monitoring and management are used in the developed countries of the world. These include America, France, Great Britain and Germany. Such techniques are Aerial Photo Interpretation (API), Closed Circuit Television (CCTV), Geographic Information Systems (GIS), Global Position System (GPS), and Remote Sensing (RS). Nevertheless, the use of many of these techniques is not in vogue in many developing countries (including Nigeria and many other African countries) because of their low level of technology.

According to Miller and Spoolman (2011:666), an environmentally literate person should have a basic comprehension of the under listed components of environmental education:

$\begin{array}{ll}\text { - } & \text { basic concepts in environmental education } \\ \text { - } & \text { principles of sustainability } \\ \text { - } & \text { knowledge of environmental history } \\ \text { - } & \text { the two laws of thermodynamics and the law of conservation of matter } \\ \text { - } & \text { human population dynamics } \\ \text { - } & \text { ways to sustain biodiversity } \\ \text { - } & \text { sustainable forestry } \\ \text { - } & \text { soil conservation } \\ \text { - } & \text { non-renewable mineral resources } \\ \text { - } & \text { non-renewable and renewable energy resources } \\ \text { - } & \text { climate change and ozone depletion } \\ \text { - } & \text { pollution prevention and waste reduction } \\ \text { - } & \text { environmentally sustainable economic and political systems } \\ \text { - } & \text { environmental worldviews and ethics } \\ \text { - } & \end{array}$

As analysed by Cunningham and Cunningham, (2006:356) an environmentally educated person knows the inter-relationships between human and his environment, understands how human society is influencing the environment, explores his values in relation to environmental issues and be involved in the activities that can maintain, improve or restore environmental resources and quality. In this sense, an environmentally educated person must have acquired some knowledge about the environment, ready to provide intellectual leadership towards rational environmental management, posses effectiveness and social utility qualities, and be willing to transfer acquired knowledge to others. Above all, he should help in the promotion of the use of environmental resources in order to ensure sustainable development.

\section{Recommendations}

The essence of environmental education is to increase environmental literacy. It also aims at overcoming environmental challenges and promoting sustainable development. The cardinal principle of environmental education therefore, is the advancement of the optimal use of earth's resources. To this end, measures towards environmental education should enlighten the people about the finite limit of environmental resources. In addition, people should understand what resources means, appreciate the significance of environmental resources, recognize human-environment interaction and its consequences on the environment, and be aware of the actions they can take in order to tackle environmental degradation.

Environmental education should encompass the process of finding lasting solutions to environmental problems. Such measures include prevention of bush fires, anti-erosion means, tree planting in degraded areas, conflict management, environmental monitoring and empowerment of local people, as well as rural development. It should also focus on prevention of animal straying, curbing of wasteful resources use, reduction of pollution, more efficient logging devices, land management, and forest resources management. Other strategies of 
environmental education are sustainable waste management, climate change mitigation, integrated watershed management, biodiversity conservation, as well as effective management of water resources.

Environmental education connotes the tutelage about the careful understanding, planning and use of environmental resources within the context of economy and sustainable development. It encompasses the promotion of clean and healthy environment through land use control, conservation management of rangeland and livestock, pollution control, poverty alleviation, control of population growth, resources sharing, practicing of efficient and environmentally sound farming, and reduction of gas flaring. Environmental education should involve the equitable, sustainable and effective management and use of environmental resources on which many people rely.

Environmental education should encompass with the political, administrative, socio and economic policies that should be taken in order to restore environmental values so as to achieve sustainability. To this end, this study recommends that it should be taught at all citadels of learning. It should be embraced by the government, individuals, scientists, environmental management staff, policy makers and the general public. For environmental problems to be reduced to the barest minimum, awareness about the socio-cultural and natural environment should be promoted. Above all, the developing nations of the world should embrace the modern techniques of environmental education and management.

\section{Conclusions}

This paper has shown the importance of the environment to humans. It has also demonstrated the necessity to protect the environment for the use and benefit of mankind. A major way of achieving this is to have the requisite information about the working mechanism of environmental system. This is attainable through the creation and spread of information, instruction, counsel and revelation about the environment.

Environmental education is a contemporary issue in environmental management and planning. It has been well embraced and adopted by developed countries of the world, while it is not in vogue in many developing countries. It is meant to inform, inspire, empower and advance people about the necessity to take care of the environment. It involves the transfer of skill and knowledge about the environment from one person to another, and from generation to generation. It entails that individuals and social groups should acquire the required awareness and knowledge about the environment. Consequently, the acquired knowledge should be used to prevent the occurrence of human-made hazards and to solve real-life environmental problems. The whole essence of environmental education is to develop a healthy environment around us.

Environmental education requires the knowledge about human-environment interaction, environment-population growth, prevention - solution to environmental problems, as well as the rational use of environmental resources. To this end, stakeholders in the environment - environmentalists, economists, students, teachers, planners, industrialists, technologists, politicians, surveyors, agriculturists, decision makers and future leaders - are required to participate in the campaign for environmental education.

Environmental education is anchored on the premise that we need to think critically about the environment. It is based on the ground that there is still much we do not understand about the environment. However, the working system of the environment is very complex. The environment itself is ever-changing and dynamic in nature. Thus, the careful, rational and intelligent use of resources is fast becoming a cornerstone to environmental management. Environmental education promotes the careful understanding, planning and sustainable use of environmental resources. This is attainable through the creation of awareness about environmental problems.

Environmental education guides against the expulsion of bad practices against the environment. Also, it creates a sense of ownership of environmental resources. It promotes problems - solving, and it enhances public involvement in decision making. Above all, environmental education intensifies development planning, transparency, accountability, as well as public-private participation in environmental management. In short, environmental education is useful for environmental managers, decision makers, planners, students, technologists, teachers, politicians and the general public. Thus, it should be carefully and methodologically taught at all levels - pre-primary, primary, secondary, technical, college of education, polytechnic and university. Above all, the tidings should be spread to the rural and urban places of developed and developing countries of the world.

\section{References}

Ademiluyi, I. L., \& Solanke, M. O. (2004). Towards effective environmental management for sustainable development in Nigeria. In O. A. Ibitoye (Ed.), Economic and social issues in population, environment and sustainable development in Nigeria (pp. 157-164). Ado-Ekiti, PETOA Educational Publishers. 
Adetuberu, J. O. (2003). Environmental education. Akure, Laseinde.

Agbogidi, O. M., \& Ofuoku, A. U. (2007). Promoting environmental protection through environmental education: the role of women. Journal of Environmental Extension, 6(1), 17-24. http://dx.doi.org/10.4314/jext.v6i1.2756.

Akinbode, A. (2002). Introductory environmental resources management. Ibadan, Daybis Limited.

Andrejs, K., Dan, R. L., \& Kelly, Y. (2013). Eco-literacy development through a framework for indigenous and environmental education leadership. Canadian Journal of Environmental Education, 8(1), 111-125.

Anil, K. D., \& Arnab, K. D. (2014). Textbook of environmental science. New Delhi, Rajan Jain.

Botkin, D. B., \& Keller, E. A. (2012). Environmental science (8th ed.). New Jersey, Wiley and Sons Inc.

Caldwel, L. K. (1973). Man and his environment: Policy and administration. New York, Harper and Row.

Cecil, M. (2014). The intergenerational transmission of environmental concern: The influence of parents and communication patterns within the family. The Journal of Environmental Education, 45(2), 77-90. http://dx.doi.org/10.1080/00958964.2013.846290

Charles, W. H. (1979). Elements of human geography. London, George Allen \& Unwin.

Cunningham, W. P., \& Cunningham, M. A. (2006). Principles of environmental science (3rd ed.). New York, McGraw-Hill.

Debbie, B. (2013). Bridges to global citizenship: Ecologically sustainable future utilising children's literature in teacher education. Australian Journal of Environmental Education, 29(2), 221-237. $\mathrm{http}: / / \mathrm{dx}$.doi.org/10.1017/aee.2014.7

Fatubarin, A. (2009a). Our environment, our legacy. Ilesha, Keynotes Publishers Limited.

Fatubarin, A. (2009b). Man and his environment. Ilesha, Keynote Publishers Limited.

Fellman, J. D., Getis, A., \& Getis, J. (2008). Human geography: landscapes of human activities (10th ed.). Boston, McGraw-Hill.

Franca, A. (2002). Strategies for participatory communal action for environmental protection. Journal of Conservation, 1(1) 24-32.

Goldsmith, E. (1988). The way: An ecological world view. The Ecologist, 18(1), 4-5.

Holden, J. (2008). Approaching physical geography. In J. Holden (Ed.), An introduction to physical geography and the environment. England, Pearson Educational Limited.

Hyde, P., \& Reeve, P. (2011). Essentials of environmental management (3rd ed.). Leicestershire, IOSH Services Ltd.

Ibimilua, A. F. (2013). Biodiversity-ecosystem management and sustainable development in Ekiti State, Nigeria. British Journal of Humanities and Social Sciences, 10(1), 71-76.

Ibimilua, A. F. (2014). Key issues in landscape planning in the context of environmental sustainability. European Scientific Journal, 10(2) 143-156.

Ibimilua, A. F., \& Ibimilua, F. O. (2011). Aspects and topical issues in human geography. Akure, B. J. Production.

Ibimilua, F. O., \& Ibimilua, A. F. (2014). Environmental challenges in Nigeria: Typology, spatial distribution, repercussions and way forward. American Journal of Social Science, 3(2) 246-253.

Ibitoye, O. A. (2004). Conceptual issues in population, environment and sustainable development. In O. A. Ibitoye (Ed.), Economic and social issues in population, environment and sustainable development in Nigeria (pp. 1-6). Ado-Ekiti, PETOA Educational Publishers.

Ike, N. (2002). Nigeria's environment in the 21st century. Being the 20th anniversary lecture of the Nigeria Conservation Foundation (NCF). Lagos, NCF.

Jain, R. K., \& Rao, S. S. (2011). Industrial safety, health and environment management system (3rd ed.). New Delhi, Dhanna Publishers.

Jimoh, H. I. (2000). Man-environment interaction. In H. I. Jimoh, \& I. P. Ifabiyi (Eds.), Contemporary issues in environmental studies (pp. 20-27). Ilorin, Haytee Press and Publishing Co. Ltd.

Kanagasabai, S. (2010). Environmental studies. New Delhi, PHI Learning Private Limited. 
Kwame, G. (2008). Social studies. Legion, Sankofa Publishing Company Limited.

Madu, I. A. (2007). Population and environmental problems. In G. E. K. Ofomata, \& P. O. Phil-Eze (Eds.), Geographical perspectives on environmental problems and management in Nigeria (pp. 80-95). Enugu, Jamoe Publisher.

Mahatma, G. (2009). Introduction. In J. Benny (Ed.), Environmental studies. New Delhi, McGraw-Hill.

Miller, G. T., \& Spoolman, S. (2011). Living in the environment. Belmont, Brooks/Cole.

Natural Environment Research Council (NERC). (2006). The environment: identifying and tackling the problem. Swindon, NERC.

Oriodon, T. (1976). Environmentalism. London, Pion.

Park, C. (1997). The environment: Principles and applications. London, Routledge.

Pepper, D. (1996). Modern environmentalism: An introduction. London, Routledge. http://dx.doi.org/10.4324/9780203412244

Peter, S. W. (1995). Introduction. In S. W. Peter, I. J. Ekpoh, \& F. E. Bisong (Eds.), Environmental education. Lagos, Nigerian Conservation Foundation.

Raven, P. H., Berg, L. R., \& Hassenzahl, D. M. (2010). Environment (7th ed.). New Jersey, John Wiley \& Sons Inc.

Santra, S. C. (2011). Environmental science. Kolkata, New Central Book Agency.

Siyanbade, D. O. (2006). Disaster management in Nigeria: Preparedness and prevention. Lagos, Olas Ventures.

Stanley, B. (2010). Caring for the environment for people. Footsteps, (82), 1-2.

Umoren, G. U. (2005). Issues in environmental education curriculum. In M. E. Iyang-Abia, \& G. U. Umoren (Eds.), Curriculum development and evaluation in environmental education (pp. 274-297). Lagos, Nigerian Conservation Foundation.

Wright, R. T., \& Boorse, D. F. (2011). Environmental science: Toward a sustainable future. New Jersey, Pearson Education Inc.

\section{Copyrights}

Copyright for this article is retained by the author(s), with first publication rights granted to the journal.

This is an open-access article distributed under the terms and conditions of the Creative Commons Attribution license (http://creativecommons.org/licenses/by/3.0/). 